\title{
THE REPAYMENT OF THE EXCISE DUTY ON GREEN DIESEL AS TAX SUPPORT FOR AGRICULTURAL PRODUCTION IN THE CZECH REPUBLIC
}

\author{
Pavel Semerád ${ }^{1}$ \\ ${ }^{1}$ Mendelova univerzita v Brně, Provozně ekonomická fakulta, Zemědělská 1/1665, 61300 Brno \\ Email:pavel.semerad@mendelu.cz
}

\begin{abstract}
This paper deals with the repayment of the excise duty on Green Diesel, which is one type of support for Czech farmers. The aim is to identify the current problems of farmers by using analysis of this support. On the basis of a model example, by comparing the farmer and the transporter, the point of view of equity of taxation is assessed. The tax burden on the transporter is greater than the tax burden on the farmer, which is against the rule of horizontal equity among tax payers. For this reason some associations propose that the government of the Czech Republic should either reduce the excise duty rate on Diesel or support other businesses too, e.g. Professional Diesel for transporters. This paper also focuses on the risk of tax evasion related to this measure. Theoretically, some ways by which tax evasion could be perpetrated are implied for farmers and predicted for transporters. In the course of the research some weaknesses which could be illegally exploited by fuel sellers for their own enrichment were identified. Another problem lies in claiming the repayment of the excise duty on Green Diesel because some wholesale fuel sellers assign different Combined Nomenclature codes to Diesel. It causes trouble to farmers when dealing with the tax authorities and it complicates smooth execution of checking. Provided Green Diesel is abolished, it is proposed to substitute it with a tax refund or an increase in the flat rate percentage of costs in the Income Tax Act.
\end{abstract}

Keywords: agriculture, equity of taxation, excise duty on Green Diesel, mineral oils, tax evasion.

JEL classification: H20, H21, H26

Doručeno redakci: 26.7.2012; Recenzováno: 2.3.2013; 1.3.2013; Schváleno k publikování: 11.9.2013

\section{Introduction}

According to the subject of taxation some goods and products can be liable to more than one indirect tax at the same time. Svirák (1998) stated that indirect taxes are collected as a part of the price of products and services. Besides the value added tax (VAT) the goods are subject to the excise duty as well. One of excise duties in the Czech Republic is the excise duty on mineral oils. The tax burden falls on the consumer but the tax is paid indirectly by the tax payer.

Excise duties, alternatively excises, are always imposed on the object (in rem). Hruška (2007) pointed out that it is not possible taking into consideration of property, revenue and social position of the tax payer. Kubátová (2009) added that equity could be done only indirectly, e.g. using rates and exemptions for goods according to the position of the tax payer who will probably buy the goods.

The Czech government tries to favour some of the tax payers and protect them against the tax impact. Agriculture is one of the areas where producers can claim a the repayment of the excise duty on mineral oils used for agricultural production ("the repayment of the excise duty on Green Diesel"). The internal regulations contain a list of activities of agricultural primary production in respect of which a the repayment of the excise duty on Green Diesel may be claimed (Celní správa, 2012). The excise duty on diesel is CZK10,950 per 1,000 litres. If all conditions are fulfilled, $60 \%$ of the excise duty rate is refunded (CZK 6.57 per litre). Because prices of fuel are going up, the excise duty rate and its impact on collecting taxes is being 
discussed. The tax rate of diesel rose by about CZK1.00 in the year 2010. The target was to increase the tax revenue for the state budget. But for the same reason consumers (truck drivers) started buying diesel in other countries which have lower rates.

Some professional associations, e.g. the Association of Petrol Stations of the Czech Republic and ČESMAD BOHEMIA, the Association of Road Transport Operators voiced their opinion that the revenue from collecting taxes decreased. They proposed that the Ministry of Finance of the Czech Republic (MFCR) should cut the tax rate of excise duty. A toll increase was offered in return (Felix, 2012).

Green Diesel as an exemption is being discussed by the government, and some political parties would like to abolish it. Hašek (2012) - the shadow Minister of Agriculture - is scared that Czech agriculture will gradually disappear. With other defenders he wants to maintain this support for farmers. However, the question is: Is taxed the way just to favour one group over the other?

The question of tax effectiveness must not be ignored. According to Koštuř́ková (2011), the state, which has a high proportion of small entrepreneurs, which is also the case of the Czech Republic, should, in the development of the tax system, more emphasize indirect taxes and try very hard to have its proportion as large as possible. The effective tax rate as an indicator measures the actual tax burden of taxpayers and unlike the statutory tax rate it can take into account the aspects of the tax system which have an impact on the resulting tax.

From the viewpoint of green diesel repayment this is not a dispute only between farmers and carriers but it is principally a complex issue that in the times of economic crisis does not ensure effective tax collection. It is important to mention that support for agriculture in the Czech Republic is not unusual, compared with the European Union, and landscape conservation is also one of the most important activities, besides e.g. food self-sufficiency.

\section{Materials and methods}

The aim of this paper is to identify the current problems of farmers by using analysis of the repayment of the excise duty on Green Diesel. This support for Czech agriculture is assessed in view of the fact that there will be equity of taxation for other businesses, e.g. road transport operators. The other aim is to propose measures for more transparent application and stronger measures against tax evasions provided some of them are detected.

In this paper standard scientific methods were used - notably analysis, comparison and description - which allowed the objective and systematic qualitative description of these problems. By using the method of analysis the current state of application of the repayment of the excise duty on Green Diesel was evaluated. During consultations with randomly selected cooperative farms in South Moravia (a total of 20) dominant problems of the repayment were pinpointed.

Selection of farmers was random and the sample included both farmers with their own tank (filled by some fuel distributors) as well as those who use petrol stations that issue the documents required for green diesel repayment. Farmers were initially contacted by telephone and asked to cooperate in identifying the problem with green diesel repayment. Subsequently, through interviews (open questions) necessary information was obtained and by the method of analysis the problems were discussed in the light of legal regulations. 
By the method of comparison model examples of tax evasion by an agricultural entrepreneur ("farmer") and a road transporter were evaluated. On the basis of the differences found, an alternative way of support for Czech agriculture was suggested. By the method of description laws were applied, significant facts were described and some changes were recommended.

\section{Results and discussion}

The Czech Republic implemented the Common Agricultural Policy of the European Union after its entry into the EU in the year 2004. It guarantees balance on the European market and prevents fluctuations in supplies of agricultural products (MZV, 2009). Farmers are offered European and national subsidy programmes (MZ CR, 2012). Outside of these financial funds farmers can claim the repayment of the excise duty on Green Diesel. Any natural person or legal entity employed in primary agricultural production that buys legally defined mineral oils or produces them by themselves and verifiably uses them for primary agricultural production is entitled to make this claim. The tax is repaid in the amount of 60\% (Diesel and Bio-Diesel) and in the amount of $85 \%$ (fuels which must have a proportion of rapeseed oil methyl ester of at least 30\% called MĚŘO or FAME (Semerád, 2011). In accordance with the Internal Directive No. 25/2008 the claimant is liable to produce a certificate that the land for which the claim is applied is used for agricultural purposes. Fuel sales can be documented by a summary report (e.g. a monthly report) instead of receipts or invoices in accordance with the conditions specified in Section 57 (9) of the Excise Duty Act.

Some other professional associations would like to implement tax credits (tax breaks) similar to Green Diesel. For example, road transporters would like to get the so-called Professional Diesel which would work on the same principles. The part of the excise duty on Diesel would be refunded to road transporters who buy and consume Diesel in the Czech Republic. Logically, this would encourage domestic road transporters and they would be motivated to buy Diesel at domestic petrol stations (Felix, 2011).

The current situation means that one group of tax payers is discriminated against in favour of another group, which is against horizontal equity from the point of view of tax theory. Horizontal equity means that tax payers should pay taxes at the same rate (Mankiw, 1999). The difference of CZK 6.57 per litre can be seen in Table 1 and Figure 1.

Table 1: Comparison of fuel tax burden between farmers and transporters

\begin{tabular}{|l|c|c|}
\hline Composition of diesel price & Farmer [CZK] & Transporter [CZK] \\
\hline Excise duty & $\mathbf{1 0 . 9 5}$ & $\mathbf{1 0 . 9 5}$ \\
\hline Purchase price at refinery & 16.33 & 16.33 \\
\hline Margin of sellers & 1.79 & 1.79 \\
\hline VAT & 5.81 & 5.81 \\
\hline The repayment of the excise duty & 6.57 & 0 \\
\hline Total price after the repayment of excise duty & $\mathbf{2 8 . 3 1}$ & $\mathbf{3 4 . 8 8}$ \\
\hline
\end{tabular}

Source: The author's own calculations. A basic weekly price of the company ČEPRO, a.s. for the week from $3^{\text {rd }}$ July to $10^{\text {th }}$ July 2012 - CZK 27.28 per litre and an average sale price of the company CCS Česká společnost pro platební karty s.r.o. for the day $5^{\text {th }}$ July 2012 - CZK 34.88 per litre were used.

Now, a question arises as to whether it would be a better solution with regard to equity of taxation to abolish Green Diesel and replace it with another subsidy. For example, an increase in a flat rate percentage of costs (natural person) or tax relief (legal entity) could be used. 
Figure 1: Graphical illustration of the composition of the price for farmers and transporters

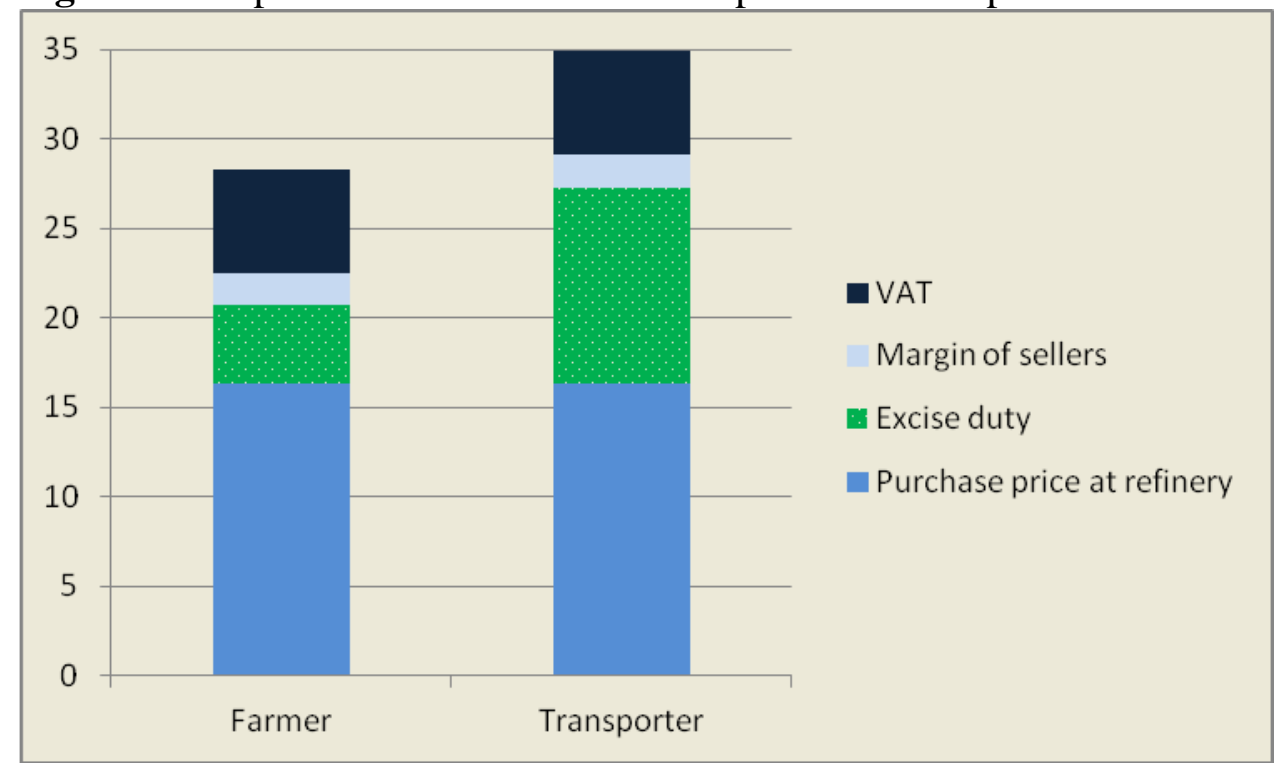

Source: The author's own calculations.

The changes in the excise duty would have their own advantages, but also disadvantages, as it follows from the conversation with some agricultural cooperatives and the tax authorities. The advantage would be making administration easier (for farmers) and reducing some tax evasions (for the customs office). On the other hand, farmers are afraid that they will not be fully compensated for the changes in the rules.

Table 2: Comparison of theoretically possible Green and Professional Diesel tax evasions

\begin{tabular}{|c|l|l|}
\hline Type of evasion & \multicolumn{1}{|c|}{ Farmer } & \multicolumn{1}{|c|}{ Transporter } \\
\hline $\begin{array}{c}\text { Consumption by } \\
\text { another subject }\end{array}$ & $\begin{array}{l}\text { Green Diesel is consumed by some } \\
\text { other consumer. The fraudster } \\
\text { reports a higher number of } \\
\text { kilometres driven (hours of } \\
\text { operation) but only in the records. }\end{array}$ & $\begin{array}{l}\text { Professional Diesel is consumed by } \\
\text { some other drivers. In case of small } \\
\text { vehicles the inspection is very difficult. }\end{array}$ \\
\hline $\begin{array}{c}\text { Consumption over } \\
\text { the limit }\end{array}$ & $\begin{array}{l}\text { Higher consumption because more } \\
\text { than just land under cultivation is } \\
\text { included. }\end{array}$ & $\begin{array}{l}\text { Average consumption is hard to } \\
\text { determine because it is dependent on a } \\
\text { number of factors, e.g. a load, road } \\
\text { surface and terrain, driver's age, } \\
\text { equipment of a vehicle, etc. }\end{array}$ \\
\hline Illegal mixing & $\begin{array}{l}\text { More bio-fuel (non-taxed) is added } \\
\text { into diesel, which is called illegal } \\
\text { mixing. }\end{array}$ & $\begin{array}{l}\text { Bio-fuel is added into diesel but for } \\
\text { accounting purposes receipts from } \\
\text { some other purchases are included. }\end{array}$ \\
\hline
\end{tabular}

Source: The author's own research.

The current calculation is based on standard consumption of fuels and purchase proved by a tax document. Some wholesale fuel companies act for their customers - farmers - before the tax authorities on the basis of a power of attorney. Table 2 provides a comparison of risks which could arise in the form of tax evasion perpetrated by farmers and road transporters through misuse of the excise duty benefits. A major problem is to ensure that Green (or Professional) Diesel is used for a specific purpose and by specific vehicles. 
By illegal mixing fuel is blended with chemical substances, compounds and mixtures that have similar technical characteristics but a lower rate of the excise duty are exempt from taxation entirely or partially (these components are destined for off - road use or for disposal) (Semerád, 2012).

Some of the cooperative farms have bad experience with claiming the repayment of the excise duty on Green Diesel because of different labelling of Diesel (combined nomenclature codes) by their supplier. This was proved true during the research. For diesel ČEPRO, a.s. uses customs classification 2710 1941, which is in agreement with the Regulation No. 133/2010 (Section 2) and with the Excise Duty Act (Para 45). Diesel fuel has CN code of 27101941 (more in Sec 2). The Act 353/2003 Section 45 allows to claim refund of the excise duty on Green Diesel falling within CN codes from 27101911 to 27101949 Section 45(1b) or 3824 9099 Section 45(2j).

Other sellers use the Combined Nomenclature Code 27102011 that complies neither with the regulation nor with the Act. This difference can cause problems to farmers claiming the refund of the excise duty on Green Diesel. The main condition is not satisfied even though Diesel is supplied from the same storehouse and conforms to the norm ČSN EN 590. Tax authorities can refuse the farmer's claim on grounds of the wrong Combined Nomenclature Code.

According to farmers a simpler classification of diesel could help in this situation. A sufficient criterion could be the quantity of methyl ester given on the tax document and its consistency with the norm ČSN EN 590. Farmers are already overburdened with paperwork and new paperwork burden does not make any sense. The reason why the obligation should be transferred from tax authorities to farmers could be debated.

\section{Conclusion}

The objective of this paper was to identify farmers' problems by performing analysis of the current method of the repayment of the excise duty on Green Diesel. As this type of support is currently being discussed by the government of the Czech Republic and some other professional associations, a comparison was made of farmers and transporters from the point of view of equity of taxation and tax evasion. Data were collected from cooperative farms and tax authorities with the aim of identifying the current problems of farmers with Green Diesel.

The results show that the repayment of the excise duty on Green Diesel poses risks of tax evasion. Petrol companies could abuse this principle for their illegal enrichment. Some cooperative farms grant external companies a power of attorney to act with tax authorities. There could be a fraud of providing incorrect information on paper about the increase in consumption of fuels, e.g. by inflating the numbers of kilometres driven or the area of the cultivated land. The same risk exists for transporters where the problem of vehicle checking and monitoring is even worse because of the norm of consumption depending on the age of vehicles, the weight of load, road surface conditions, etc. The same refund frauds and tax evasions are imminent if fuel is not used for transport business.

A solution to this problem could be to cancel Green Diesel, which is supported by the Czech Republic and to find an alternative way of support. But by doing this the Czech Republic will be together with the Slovak Republic an exemption in the European Union policy. The other member states in the European Union have measures such as Green Diesel. Therefore an increase in a flat-rate percentage of costs (natural person) or one-time tax relief (legal entity) 
is some of the solutions to consider. On the other hand, the importance of agriculture and also tax effectiveness must not be overlooked.

The current method of the repayment of the excise duty on Green Diesel is connected with some complications with customs classification of Diesel. Based on the research no unified classification of petrol sellers was discovered, which causes difficulty in proving the claim for a replacement. For this reason, the following proposal could make the process of classification much easier - the invoice should include the quantity of methyl ester and declare its consistency with the norm ČSN EN 590.

As petrol companies know about this problem, they are changing the classification of Combined Nomenclature for farmers. They can do this for untaxed mineral oils added to fuel (illegal mixing) and get involved in tax evasion. Farmers can do just very little about the classification based on the Combined Nomenclature, but they are penalized for breaking the rules. The proposed solution should make agricultural business easier and eliminate doubts over farmers' filing claims for refund.

\section{Acknowledgement}

This paper was supported by the Internal Grant Agency IGA, Grant Project No. 25/2012 called "Equity of taxation in the conditions of the Czech Republic (Daňová spravedlnost $\mathrm{V}$ podmínkách České republiky)“ at the Faculty of Business and Economics, Mendel University in Brno.

\section{References}

[1] Act No. 235/2004 Coll., on value added tax, as amended.

[2] Act No. 353/2003 Coll., on excise duty, as amended.

[3] Custom Administration of the Czech Republic., 2012. Zelená nafta. [Online]. [cit. $5^{\text {th }}$ May 2012]. Accessible on the Internet: http://www.celnisprava.cz/cz/dane/spotrebnidane/mineraly/Stranky/ZN.aspx

[4] ČSN EN 590 Motorová paliva - Motorové nafty - Technické požadavky a metody zkoušení.

[5] FELIX, M., 2012. Nedostatek odvahy i informací ministra Kalouska. [Online]. ČESMAD BOHEMIA. 12 $2^{\text {th }}$ April 2012. [cit. $5^{\text {th }}$ July 2012]. Accessible on the Internet: http://www.prodopravce.cz/zprava-i7928.php

[6] HRUŠKA, J., 2007. Daňová propedeutika. 1. vyd. Brno: Sting. ISBN 978-80-86342-689.

[7] KOŠTUŘÍKOVÁ, I., 2011. Corporate tax burden in the Czech Republic and European Union. Acta academica karviniensia. No. 2, 77-90. ISSN 1212-415X.

[8] KUBÁTOVÁ, K., 2009. Daňová teorie: úvod do problematiky. Praha: ASPI. ISBN 97880-7357-423-9.

[9] MANKIW, N. G., 1999. Zásady ekonomie. Praha: Grada. ISBN 80-7169-891-1.

[10] Ministry of Agriculture of the Czech Republic., 2012. Dotace. [online]. [cit. $6^{\text {th }}$ July 2012]. Accessible on the Internet: http://eagri.cz/public/web/mze/dotace 
[11] Ministry of Foreign Affairs of the Czech Republic (MZV)., 2009. Společná zemědělská politika Evropské unie. [online]. 22 ${ }^{\text {nd }}$ May 2009. [cit. 6 ${ }^{\text {th }}$ July 2012]. Accessible on the Internet: http://www.businessinfo.cz/cs/clanky/spolecna-zemedelska-politika-evropske5147.html

[12] SEMERÁD, P., 2011. Je zelená nafta v ohrožení?. Zemědělec. 22/2011. p. 4 ISSN 12113816.

[13] SEMERÁD, P., 2012. Value added tax evasion and the excise duty fraud on fuel market in the Czech Republic. Acta univ. agric. et silvic. Mendel. Brun. LX. No. 2. 335-340. ISSN 1211-8516.

[14] SVIRÁK, P., 1998. Daňové teorie. Brno: Fakulta podnikatelská VUT v Brně. ISBN 80214-1085-X.

[15] Vnitřní pokyn 25/2008. Sjednocení postupu celních úřadů při aplikaci ustanovení $§ 57$ odst. 6 zákona č. 353/2003 Sb., o spotřebních daních.

[16] Vyhláška č. 14/2010 Sb., kterou se mění vyhláška č. 48/2008 Sb., o způsobu výpočtu nároku na vrácení spotřební daně zaplacené v cenách některých minerálních olejů spotřebovaných v zemědělské prvovýrobě, ve znění vyhlášky č. 395/2008 Sb.

[17] Vyhláška č. 133/2010 Sb., vyhláška ze dne 5. května 2010 o požadavcích na pohonné hmoty, o způsobu sledování a monitorování složení a jakosti pohonných hmot a o jejich evidence (vyhláška o jakosti a evidence pohonných hmot) 